\title{
4 KANALOWY MODUŁ LED DO SYSTEMU WSPOMAGAJĄCEGO ROZWÓJ ROŚLIN
}

\author{
Tomasz Cegielski ${ }^{1,2}$ \\ ${ }^{1}$ Instytut Elektrotechniki, Studia Doktoranckie, ${ }^{2}$ NIVISS Sp. z o.o. Sp. k., Gdynia
}

Streszczenie. $W$ artykule przedstawiono modut oświetleniowy z 24 diodami elektroluminescencyjnymi sterowanymi w 4 niezależnych kanałach. Przeznaczony jest on do pracy $w$ systemach wspomagających rozwój roślin. Jego modułowa konstrukcja oraz elastyczność w doborze elementów umożliwia dopasowanie go do wymagań wielu gatunków i odmian roślin w różnych fazach rozwoju. Moduły moga pracować w rozbudowanych systemach jak również samodzielnie po uprzednim zaprogramowaniu. Jako przykład zastosowania zaprezentowano projekt modernizacji fitotronu do badań fizjologii roślin.

Slowa kluczowe: LED, naświetlanie roślin, fotosynteza, fotomorfogeneza, system oświetleniowy, DMX512

\section{CHANNEL LED MODULE FOR USE IN GROW LIGHTING SYSTEM}

\begin{abstract}
LEDs module with 4 independent controlled channels is presented. It can be used in plant grow lighting system. Its modular design and flexibility in the choice of components allows module to be adjusted to the requirements of many species and varieties of plants in various stages of growth. The modules can operate in complex systems and after preprogramming independently as well. As an example, plant growth room modernization project is presented.
\end{abstract}

Keywords: LED, plant lighting, photosynthesis, photomorphogenesis, lighting control system, DMX51

\section{Wstęp}

Intensywna i całoroczna hodowla roślin w krajach o klimacie umiarkowanym lub chłodnym wymaga doświetlania roślin. Światło - jego ilość i rodzaj decyduje nie tylko o odżywianiu roślin w procesie fotosyntezy ale decyduje też o fotomorfogenezie czyli inicjowaniu lub hamowaniu niektórych procesów fizjologicznych [2].

Odpowiedni dobór światła może nie tylko umożliwić lub przyśpieszyć wzrost rośliny ale ją również odpowiednio uformować - poprawić jakość, wymusić dogodny czas kwitnienia, plonowania czy ułatwić późniejszy transport.

Półprzewodnikowe źródła światła umożliwiają uzyskanie odpowiedniego rozkładu widmowego i natężenia napromieniowania kwantowego potrzebnego do właściwego doświetlania roślin. Zostało to potwierdzone w wielu badaniach $[3,5]$. Ponadto charakteryzują się wysoką efektywnością, długą żywotnością i brakiem szkodliwych substancji [4].

Wydajny i elastyczny system oświetleniowy wspomagania rozwoju roślin może więc powstać w oparciu o półprzewodnikowe źródła światła. Wymaga on wykorzystania opraw które można dostosowywać do aktualnych potrzeb roślin takich jak przedstawiony $w$ referacie moduł LED.

\section{Wymagania dla oświetlenia wspomagającego rozwój roślin}

$\mathrm{Na}$ wzrost i plonowanie roślin ma wpływ wiele czynników: jak temperatura, wilgotność, stężenie $\mathrm{CO}_{2}$ czy rodzaj podłoża. Ale to światło jest najważniejszym czynnikiem i oddziałuje na szereg procesów fizjologicznych. Substancje które funkcjonują jako fotoreceptory to barwniki roślinne, ich budowa umożliwia przekazanie roślinie energii światła (barwniki fotosyntetyczne, np.: chlorofil, karetonoidy) lub informacji o świetle (barwniki fotomorfogeniczne, np.: fitochrom, kryptochrom, fototropiny).

W przeciwieństwie do krzywej czułości ludzkiego oka podstawowe barwniki posiadają maksima absorpcji nie dla barwy zielonej ale dla niebieskiej i czerwonej (rysunek 1). $\mathrm{Z}$ tego też powodu pomiar luksomierzem jest nieodpowiedni do określenia natężenia oświetlenia lamp do doświetlania roślin. Do tego właściwe jest określenie powierzchniowej gęstości strumienia w zakresie PAR (Photosyntetic Active Radiation - promieniowanie fotosyntetycznie czynne), uwzględnia się $\mathrm{w}$ ten sposób $\mathrm{W}$ pomiarach $\mathrm{w}$ większym stopniu zakresy widma absorbowane przez rośliny. PAR może być określany $w$ jednostkach energetycznych $\mathrm{W} / \mathrm{m}^{2}$ lub częściej ze względu na kwantowycharakter procesu fotosyntezy $\mathrm{w} \mu \mathrm{mol} / \mathrm{m}^{2} / \mathrm{s}$.

Tylko niewielka część promieniowania dochodzącego do rośliny jest wykorzystywana na potrzeby fotosyntezy. Świetlnypunkt kompensacyjny, czyli poziom promieniowania dla którego równoważone są procesy oddychania i fotosyntezy, mieści się pomiędzy $1 \mu \mathrm{mol} / \mathrm{m}^{2} / \mathrm{s}$ (dla roślin cieniolubnych) do 20 $\mu \mathrm{mol} / \mathrm{m}^{2} / \mathrm{s}$. Natomiast punkt wysycenia powyżej którego zwiększanie poziomu promieniowania nie powoduje wzrostu intensywności fotosyntezy mieści się w zakresie od $40 \mu \mathrm{mol} / \mathrm{m}^{2} / \mathrm{s}$ do $400 \mu \mathrm{mol} / \mathrm{m}^{2} / \mathrm{s}$ (dla roślin światłolubnych) [4]. System oświetlający lub doświetlający rośliny powinien umożliwić uzyskanie zbliżonych poziomów.

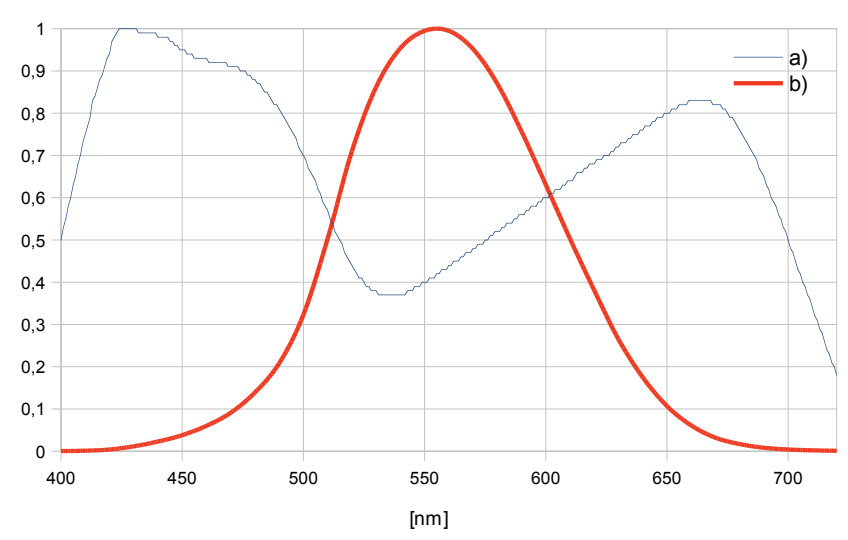

Rys. 1. a) Widmo czynnościowe fotosyntezy roślin. b) Krzywa czułości względnej oka ludzkiego dla widzenia fotopowego $V(\lambda)$

Oświetlenie wspomagające rozwój roślin powinno emitować światło o długościach fali zbliżonych do tych dla których występują maksima absorbcji barwników. Dla chlorofili są to $439 \mathrm{~nm}, 453 \mathrm{~nm}, 642 \mathrm{~nm}$ i $662 \mathrm{~nm}$, dla fitochromu $660 \mathrm{~nm}$ i $735 \mathrm{~nm}$ dla kryptochromów i fototropiny pomiędzy 370 a 500nm [4].Czyli jest to światło z zakresu od bliskiego ultrafioletu do niebieskiego oraz od czerwieni do bliskiej podczerwieni. Tylko karotenoidy, które mają w większości przypadków znikome znaczenie, absorbują promieniowanie o widmie znajdującym się pomiędzy tymi zakresami. Diody elektroluminescencyjne emitujące światło ultrafioletowe i niebieskie oparte są na technologii GaN, natomiast czerwone i podczerwone na technologii GaP lub GaAs [5]. Wiąże to się $\mathrm{z}$ różnymi spadkami napięć występującymi na emiterach światła podczas pracy $\mathrm{Z}$ takimi prądami $\mathrm{W}$ zależności od zastosowanego typu diody i musi to zostać wzięte pod uwagę podczas projektowania sterownika.

Dla fotomorfizmu istotne są nie tylko wartości energii dostarczanej $\mathrm{w}$ odpowiednich zakresach widma, ale również proporcje pomiędzy różnymi barwami. Dotyczy to szczególnie stosunku czerwieni $(\sim 665 \mathrm{~nm})$ do dalekiej czerwieni $(\sim 730 \mathrm{~nm})$, która $\mathrm{w}$ naturze $\mathrm{w}$ przeciwieństwie do zwykłej czerwieni jest przepuszczana przez tzw. okap roślinny. Rośliny reagują też na fotoperiodyzm. Do właściwego rozwoju potrzebują odpowiednich przerw pomiędzy naświetleniami. 
Ponadto przy projektowaniu systemu oświetlającego rośliny należy uwzględnić to, że różne reakcje na te same bodźce mogą występować nawet w obrębie tego samego gatunku dla różnych odmian [6]. Wszystko to powoduje konieczność posiadania możliwości zmiany parametrów oświetlenia nie tylko w cyklu dobowym, ale również pomiędzy kolejnymi dniami. Jest to istotne zwłaszcza podczas okresów krytycznych rozwoju rośliny, czyli kiedy są one szczególnie wrażliwe na brak lub obecność czynników środowiskowych, są to np. kiełkowanie czy rozpoczęcie kwitnienia.

\section{Budowa modułu}

Prezentowany moduł (schemat blokowy przedstawiony jest na rysunku 2) składa się: z płytki drukowanej na podłożu z rdzeniem aluminiowym (MCPCB - Metal Core Printed Circuit Board), soczewki z uszczelką, radiatora, przetwornic DC/DC z wyjściem stałoprądowym, 4 kanałowego kontrolera DMX512 oraz zasilacza AC/DC.

Na płytce MCPCB znajdują się 4 łańcuchy po 6 LEDów. Intensywność świecenia każdego $\mathrm{z}$ łańcuchów ustawiają przetwornice sterowane sygnałem PWM generowanym przez kontroler. Kontroler może być sterowany za pomocą protokołu DMX512 [7] lub realizować wgrany uprzednio program.

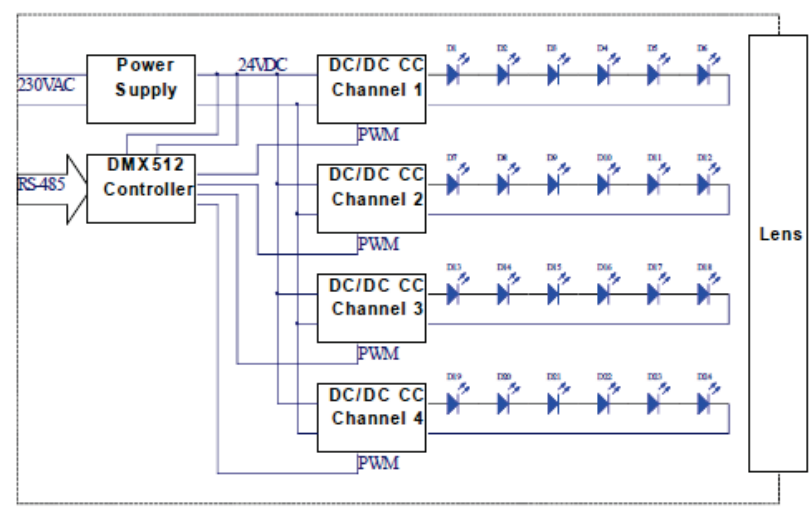

Rys. 2. Schemat blokowy modutu LED

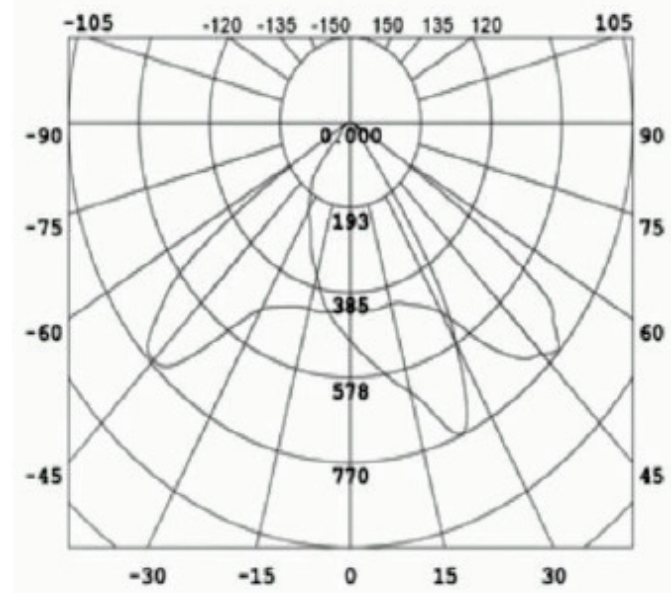

Rys. 3. Krzywe rozsylu świattości dla soczewki LL24CR-AU75135L

Zastosowana soczewka LL24CR-AU751351 [8] kieruje światło w sposób odpowiedni dla lampy ulicznej, umożliwia to zwartą konstrukcję lampy zbudowanej na podstawie przedstawionego modułu. Jest ona również uniwersalna: można ją zastosować jednocześnie $\mathrm{z}$ LEDami różnych rodzin i producentów, łatwiej dzięki temu będzie uzyskać pożądaną charakterystykę widmową.

Kształt wiązki światła dla tej soczewki jest przedstawiony na rysunku 3. Jak widać oświetlany głównie jest pas podłoża przed normalną do płaszczyzny modułu. Dzięki temu nie trzeba umieszczać lampy bezpośrednio nad uprawą - ułatwia to montaż takiej oprawy np. przez przymocowanie do elementów konstrukcyjnych szklarni i nie zasłania dzięki temu promieniowania słonecznego w przypadku doświetlania uprawy.

\section{Funkcjonalność systemu opartego na prezentowanym module}

System wykorzystujacy przedstawiony moduł wykorzystuje do komunikacji pomiędzy jednostką centralą a modułami protokół DMX512. Jeżeli pojedyncza oprawa składałaby się $\mathrm{z}$ dwóch modułów, to zawierałaby 8 oddzielnych kanałów. Wówczas w systemie przy wykorzystaniu jednego uniwersum DMX możnaby niezależnie sterować 64-ma strefami. W ramach jednej strefy może występować wiele opraw o tych samych adresach. Należy jedynie pamiętać o zachowaniu reguł elektrycznych dla standardu RS-485, który stanowi warstwę fizyczną protokołu.

W przypadku niewielkich systemów jest możliwość pracy bez centrali DMX, każda z opraw realizowałaby wówczas program zawarty w kontrolerze.

Podstawowym zadaniem systemu jest dostarczenie odpowiedniego promieniowania PAR do naświetlanych roślin. Powinno mieć ono odpowiednie $\mathrm{w}$ danej fazie rozwoju i porze dnia widmo i energię. System pozwala również na kontrolę zużycia energii - ściemnianie poszczególnych kanałów wiąże się ze zmniejszeniem jej poboru.

\section{Przykladowe zastosowanie}

Przeanalizowano możliwość modernizacji jednego z fitotronów znajdujących się w Laboratorium Pomorskiego Parku Naukowo-Technologicznego w Gdyni. Widok ustawienia regału $\mathrm{w}$ pomieszczeniu jest przedstawiony na rysunku $4 . \mathrm{Na}$ przeciwległej ścianie jest ustawiony taki sam regał Obecnie każda z podwójnych półek jest oświetlona 4 świetlówkami typu TLD840 58W. Wyliczone w programie DIALux [9] natężenie oświetlenia na płaszczyźnie, na której ustawiane są próbki jest widoczne na rysunku 5 .

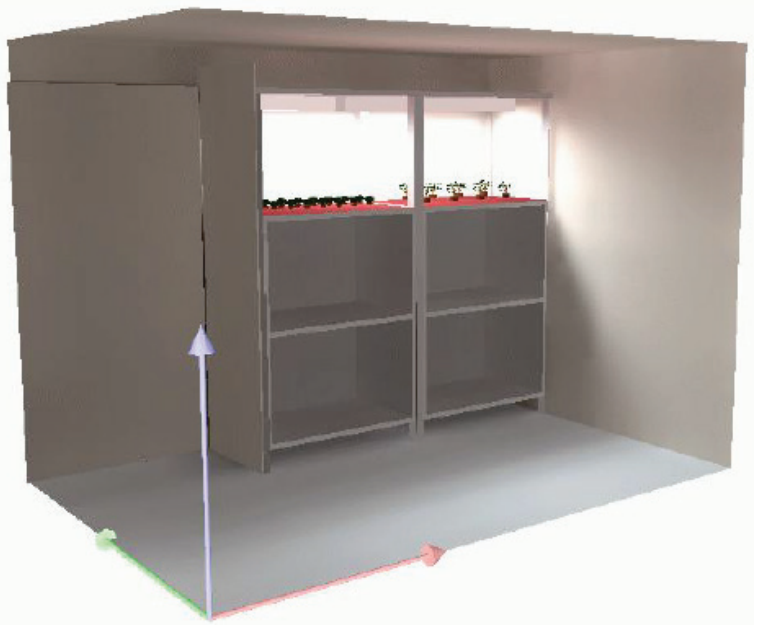

Rys. 4. Widok fitotronu z oświetlona analizowana plaszczyzna

Wymieniając każdą podwójną oprawę świetlówkową na jeden moduł LED można uzyskać porównywalną równomierność natężenia oświetlenia. Wyliczenia (rysunek 6) zostały wykonane dla założenia takiego samego strumienia świetlnego modułu LED jak oprawy świetlówkowej. Mają one na celu jedynie porównanie równomierności rozkładu światła a nie ich wartości.

Brak symetrii w prezentowanych wynikach wynika z obecności odbijających światło ścian pomieszczenia - regał jest ustawiony w rogu fitotronu.

Wartość PAR w przypadku zastosowania modułu LED wzrośnie dodatkowo w porównaniu do lampy fluorescencyjnej $\mathrm{z}$ uwagi na brak składowej zielonej $\mathrm{w}$ widmie. Szacuje się, że dzięki temu pobór energii elektrycznej, przy zachowaniu tych 
samych wartości PAR, spadnie dwukrotnie, pomimo porównywalnej sprawności w $1 \mathrm{~m} / \mathrm{W}$. Dodatkowo każda z oświetlanych półek uzyska możliwość niezależnego ustawienia parametrów oświetlenia zależnie od potrzeb danego doświadczenia.

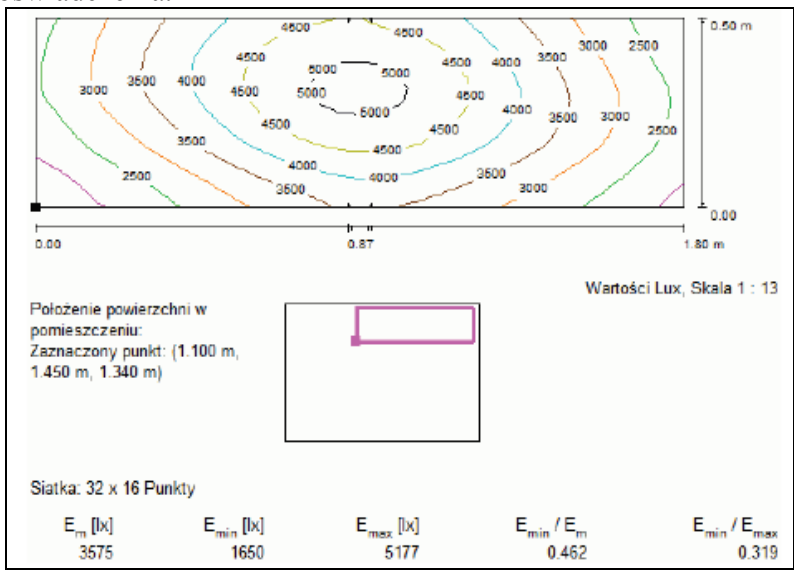

Rys. 5. Izolinie wyliczone dla oświetlenia lampami fluorescencyjnymi

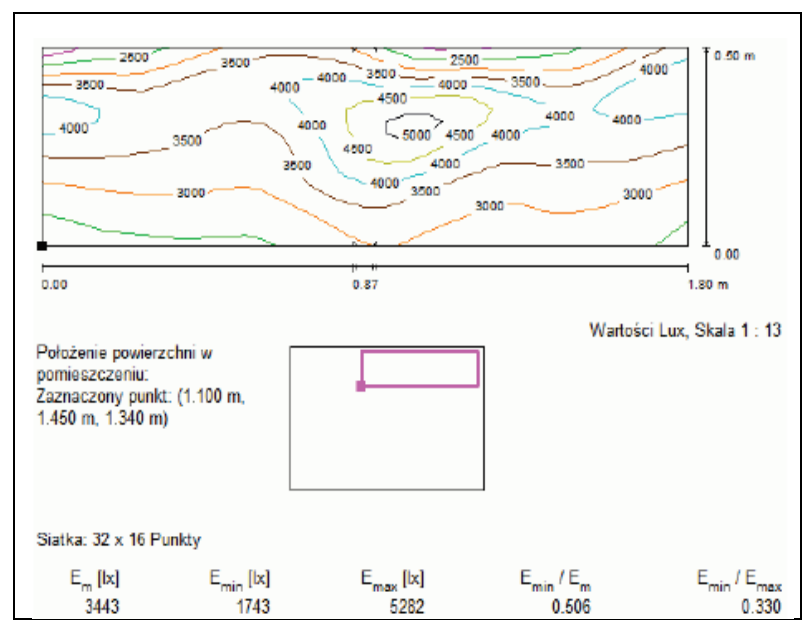

Rys. 6. Izolinie wyliczone dla oświetlenia modułami LED

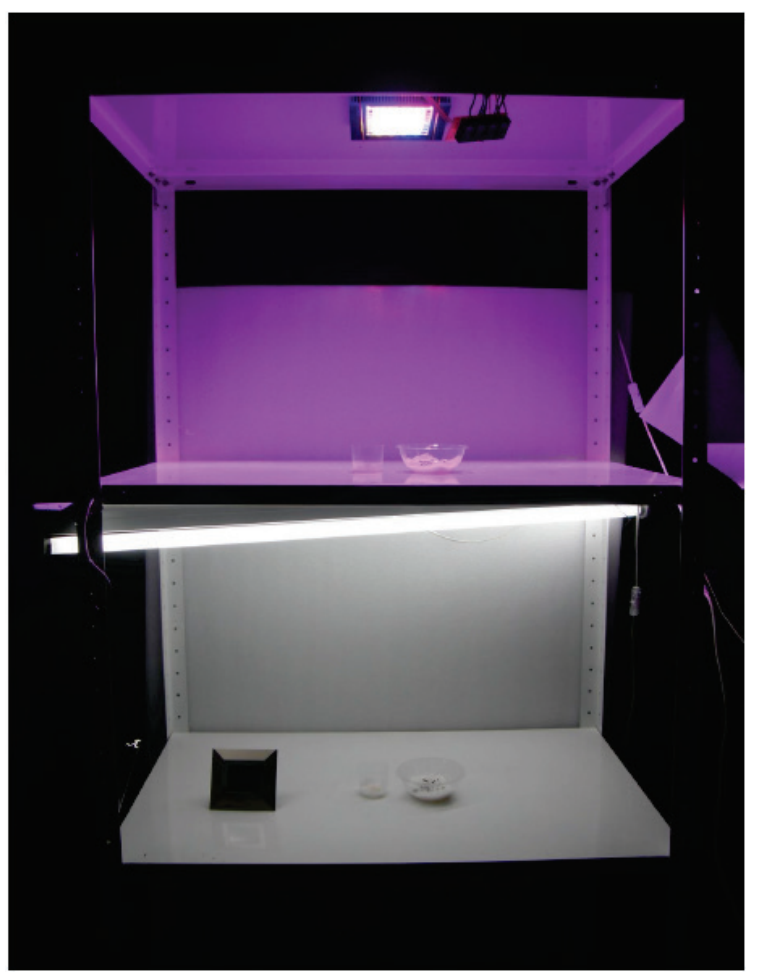

Rys. 7. Fotografia modelu fitotronu

\section{Model modułu do oświetlenia fitotronu}

W pomieszczeniu ciemni fotometrycznej NIVISS wydzielono fragment symulujący fitotron (rysunek 7). Ustawiono w nim regał o identycznych wymiarach, jedną $\mathrm{z}$ półek oświetlono oprawą $\mathrm{z}$ świetlówką, drugą modelem przedstawianego modułu LED. Temperatura oraz wilgotność było kontrolowana i stabilizowana.

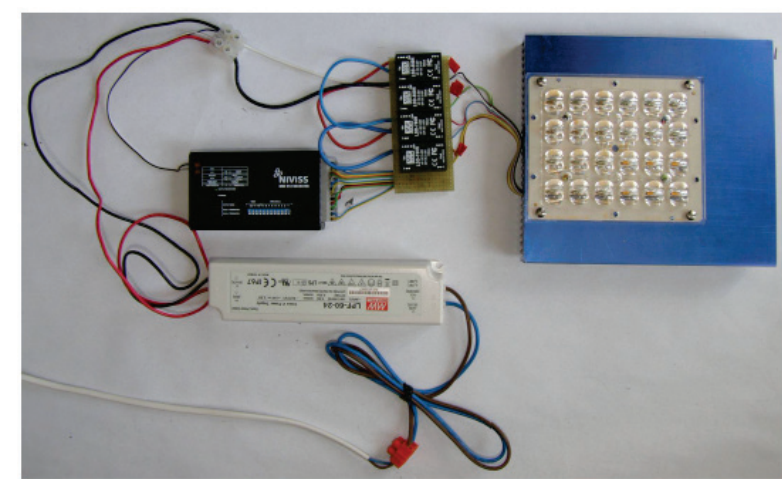

Rys. 8. Fotografia kompletnego modelu modutu

a)

\begin{tabular}{ccc|}
\hline 15 & 20 & 17 \\
+ & + & + \\
15 & 20 & 16 \\
+ & + & + \\
14 & 16 & 13 \\
+ & + & + \\
\hline
\end{tabular}

b)

\begin{tabular}{|ccc|}
\hline 39 & 40 & 38 \\
+ & + & + \\
40 & 41 & 39 \\
+ & + & + \\
32 & 30 & 32 \\
+ & + & + \\
\hline
\end{tabular}

Rys. 9. Pomierzone wartości PAR, a) pótka oświetlona świetlówka, b) pótka oświetlona modutem LED

Wykonany model (rysunek 8) zawiera łańcuchy LEDów o następujących dominujących długościach fali: $452,5 \pm 2,5 \mathrm{~nm}$, $472,5 \pm 2,5 \mathrm{~nm}, 625,5 \pm 2,5 \mathrm{~nm}$ oraz diodę białą o temperaturze barwowej 2800K. Barwne to LEDy z serii XP-E a biała to XP-E High-Efficiency White [9]. Z uwagi na przeznaczenie tego konkretnego modułu do udziału $\mathrm{w}$ doświadczeniu $\mathrm{z}$ obserwacją samego kiełkowania roślin nie umieszczono LEDów z zakresu dalekiej czerwieni.

Moc oprawy świetlówkowej wyniosła 35W a modułu LED przy pełnym wysterowaniu $36 \mathrm{~W}$. Miernikiem promieniowania fotosyntetycznie czynnego (QMSS-E apogee instr.) wykonano pomiary rozkładu wartości PAR na obu półkach. Ponieważ wartości dla półki oświetlonej modułem LED (maksimum $50 \mu \mathrm{mol} / \mathrm{m}^{2} / \mathrm{s}$ ) przekraczały ponad dwukrotnie wartości dla półki referencyjnej (maksimum $20 \mu \mathrm{mol} / \mathrm{m}^{2} / \mathrm{s}$ ) wysterowanie dla modułu LED zmniejszono do $80 \%$ i jej pobór mocy wyniósł wówczas 29,4W. Porównanie wartości PAR półek oświetlanych przez tak wysterowanego moduł LED i oprawę z świetlówką jest przedstawione na rysunku 9.

Za pomoca spektrometru Ocean Optics USB2000 wykonano pomiary widma dla włączonego całego modułu oraz pojedynczych kanałów wysterowanych na $100 \%$. Dla porównania zmierzono też widmo przykładowej lampy z świetlówkami fluorescencyjnymi liniowymi (MASTER TL-D Super 36W/840). Wyniki pomiarów z odległości $2 \mathrm{~m}$ w jednostkach względnych są przedstawione na rysunku 10. Możliwość wysterowania każdego z kanałów w zakresie $1-100 \%$ pozwala na uzyskanie wielu pośrednich charakterystyk widmowych i tym samym ustawienie światła korzystnego dla doświetlanego gatunku i fazy rozwoju. 

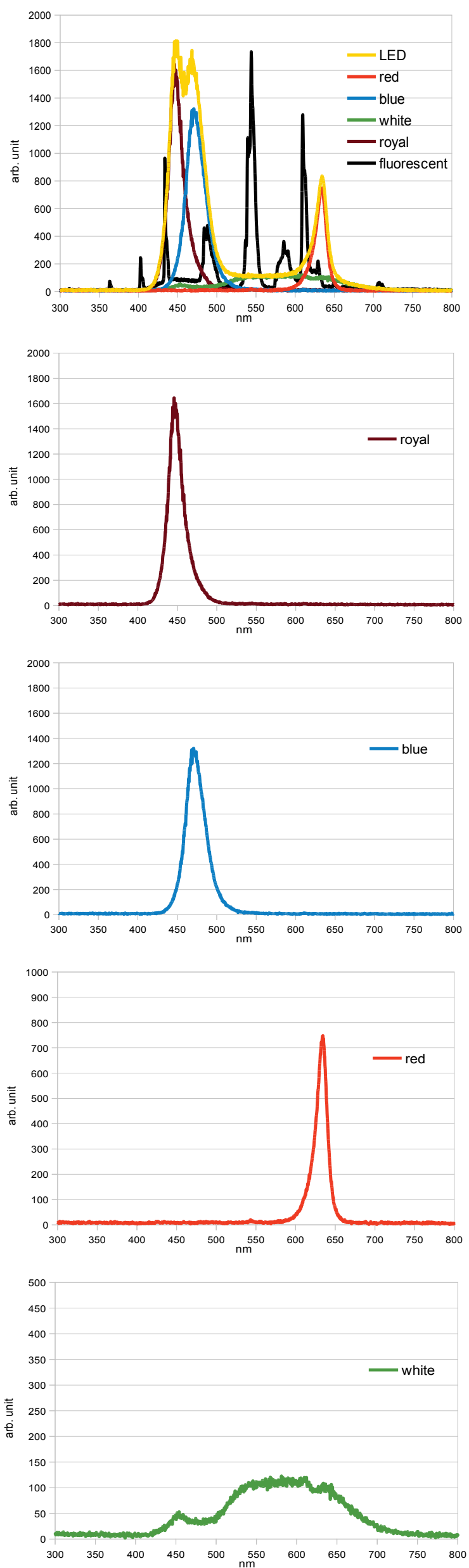

Rys. 10. Pomierzone widmo każdego z kanatów modulu oddzielnie $i$ wszystkich razem oraz lampy fluorescencyjnej

\section{Eksperyment}

17.09.2012r. zostały wysiane nasiona brokułu (Brassica oleracea L. var. italica Plenck, odmiana Cezar) w trzech kuwetach po 50 sztuk. Jedna została umieszczona na parapecie okna wschodniego, a pozostałe dwie w modelu fitotronu na środku odpowiednich półek $z$ oświetleniem fluorescencyjnym i LEDowym. Jako podłoże została użyta wata utrzymywana w stałym nawilgoceniu poprzez podlewanie 3 razy w tygodniu. Temperatura powietrza była utrzymywana $\mathrm{w}$ zakresie $21-24^{\circ} \mathrm{C}$, wilgotność 45-50\%. Naświetlanie następowało w cyklach: 12 godzin włączenie - 12 godzin wyłączenie, bez stanów pośrednich. $\mathrm{Z}$ uwagi na wysiew $\mathrm{w}$ okresie równonocy próbka kontrolna również miała zbliżony fotoperiodyzm. W kuwecie oświetlanej światłem dziennym poprzez szybę okienną wzeszło 19 sadzonek, $\mathrm{w}$ obu kuwetach w fitotronie po 30. Porównanie widoku roślin $\mathrm{z}$ półki $\mathrm{z}$ oświetleniem fluorescencyjnym i LEDowym po 10 dniach od zasiania jest przedstawione na rysunku 11. Można wyraźnie zaobserwować, że oświetlenie LEDowe skutkuje bardziej krępymi i rozłożystymi sadzonkami. 5 października nastąpił koniec eksperymentu. Wśród sadzonek oświetlonych LEDami połowa miała wykształcone już 4 liście, podczas gdy w pozostałych nie było żadnej takiej rośliny. Zostały pomierzone długości i szerokości wszystkich wyhodowanych roślin. Wyniki są zaprezentowane w tabeli 1
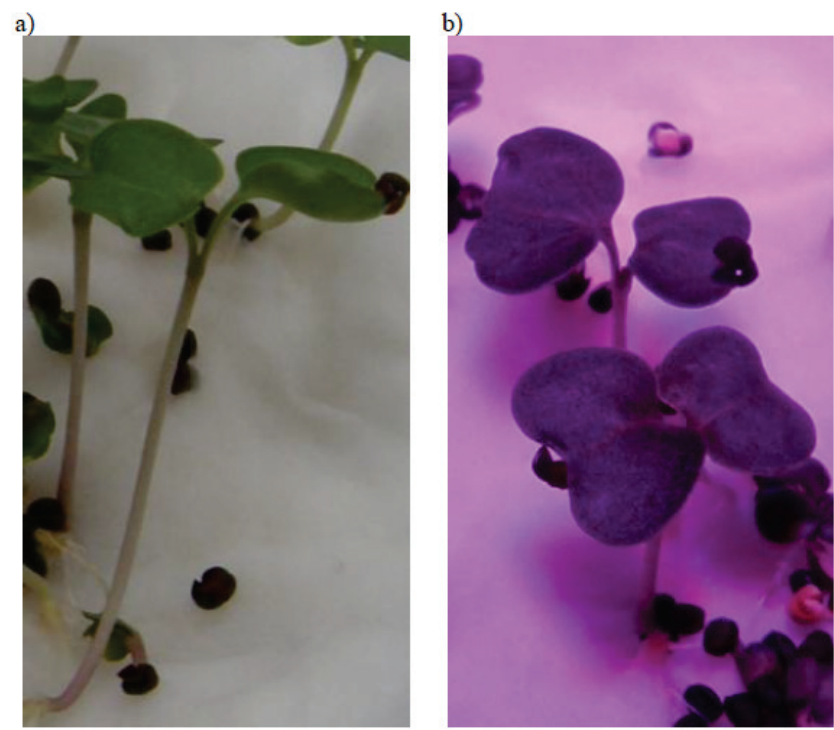

Rys. 11. Sadzonki wyhodowane przy oświetleniu: a)fluorescencyjnym, b) LEDowym

Tabela 1. Wymiary siewek Brokuła wyhodowanych przy różnym oświetleniu

\begin{tabular}{|c|c|c|c|}
\hline oświetlenie & słoneczne & fluorescencyjne & LED \\
\hline ilość wzeszłych sadzonek & 19 & 30 & 30 \\
\hline maksymalna wysokość [mm] & 52 & 28 & 25 \\
\hline średnia wysokość[mm] & 20,5 & 20,5 & 16 \\
\hline maksymalna szerokość[mm] & 18 & 22 & 24 \\
\hline średnia szerokość[mm] & 13 & 14,5 & 17 \\
\hline
\end{tabular}

Różnice w rodzaju światła spowodowały wyraźne zmiany budowie roślin. Większa ilość barwy niebieskiej oraz zupełny brak dalekiej czerwieni zgodnie z [2] powoduje skrócenie hipokotylu (podliścieniowej część łodygi w siewce, pomiędzy korzeniem zarodkowym a miejscem osadzenia liścieni) oraz zwiększenie powierzchni liści.

\section{Wnioski}

Przedstawiony moduł LED umożliwia stworzenie wydajnego i elastycznego systemu doświetlania lub naświetlania roślin. Zastosowanie go może umożliwić wpływanie nie tylko na fotosyntezę, ale również na fotomorfogenezę. Pozwoli to na 
np. poprawę plonowania [5], uzyskiwanie roślin lepiej przystosowanych do transportu albo wstrzymanie kwitnienia przed dostarczeniem sadzonek do sklepu [6].

Dodatkowo dzięki zastosowaniu półprzewodnikowych źródeł światła charakteryzuje się dłuższą żywotnością i mniejszym poborem mocy niż stosowane powszechnie systemy oparte na lampach wyładowczych

\section{Literatura}

[1] Gajc-Wolska, J. Kowalczyk K., Marcinkowska, M., Bujalski D., Hemka L. Wplyw rodzaju źródła światta na wybrane parametry fizjologiczne roślin pomidora, Prace Instytutu Elektrotechniki, rok: 2012, Z. 256, s. 67-74.

[2] Kopcewicz J., Lewak S.: Fizjologia roślin. PWN, Warszawa 2002.

[3] Puternicki A.: Zastosowanie pótprzewodnikowych źródet światta do wspomagania wzrostu roślin, Prace Instytutu Elektrotechniki, rok: 2010, Z. 245, s. 69-86.

[4] Schubert E. F.: Light-Emitting Diodes, Second Edition, Cambridge Univ. Press, New York, 2006

[5] Tamulaitis G., Duchovskis P., Bliznikas Z., Breivë K.: Ulinskaitë R., Brazaitytë A., Novièkovas A. i Žukauskas A., High-power light-emitting diode based facility for plantcultivation, J Phys D-appl Phys 38(2005), 3182-3187.
[6] Woźny A.: Zastosowanie światta $w$ kontroli wzrostu $i$ rozwoju roślin ozdobnych, Prace Instytutu Elektrotechniki, rok: 2012, Z. 256, s. 225-234.

[7] ANSI E1.11 Entertainment Technology - USITT DMX512-A, Asynchronous Serial Digital Data Transmission Standard for Controlling Lighting Equipment and Accessories, www.esta.org

[8] www.ledlink-optics.com

[9] www.cree.com/led-components-and-modules/products

[10] www.dial.de/DIAL/en/home.html

\section{Mor inż. Tomasz Cegielski}

e-mail: tc@niviss.com

Absolwent Wydziału Elektroniki i Technik Informacyjnych Politechniki Warszawskiej (1998). Do 2006 asystent w PIT, gdzie przedmiotem jego pracy były mikrofalowe podzespoły urządzeń rozpoznania radiolokacyjnego. Następnie kierownik Laboratorium Innowacyjno-wdrożeniowego w TeleMobile Electronics. Od 2009 główny konstruktor NIVISS - firmy dostarczającej rozwiązania oparte na LED. Członek IEEE od 2008.

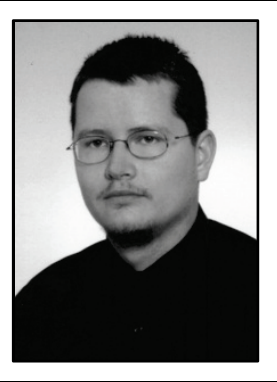

Artykuł recenzowany

\title{
INTERNATIONAL INTERDISCIPLINARY PHD WORKSHOP I ${ }^{2}$ PHDW2013
}

\section{BRNO, CZECH REPUBLIC, 08 - 11 SEPTEMBER 2013}

\author{
http://www.utee.feec.vutbr.cz/files/iiphdw2013
}

Organized by:
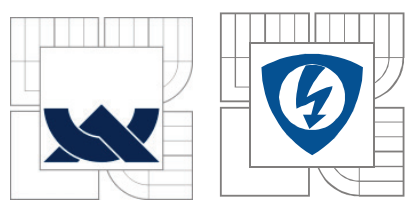

Brno University of Technology The Faculty of Electrical Engineering and Communication

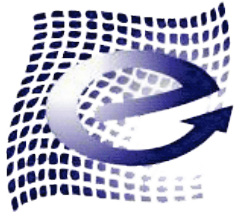

Lublin University of Technology Institute of Electronics and Information Technology

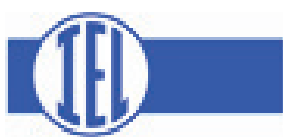

Electrotechnical Institute Warsaw

\section{IMPORTANT DATES}

30.03.2013$30.04 .2013-$ $30.05 .2013-$

30.06.201330.07.20138.-11.09.2013-

Abstract submission (on-line)
Notification of Acceptance of the abstracts
Full paper submission, Registration Fee
Payment, Accommodation Booking
Notification of Paper Acceptance
Final Paper Submission
IIPhDW Workshop

\section{SUBMISSION GUIDELINES}

You are invited to submit 1 paper (max. 5 pages) for the $I^{2} \mathrm{PhDW} 2013$. The paper should follow exactly the form outlined in the template (click on the link to download the template in the doc file format). Each author is expected to emphasize the main points and novel features of his or her work, including the results. The paper should be submitted in the PDF format directly via the Workshop website.

\section{ELECTRONIC SUBMISSION WEBSITE}

The format and style templates can be downloaded from http://www.utee.feec.vutbr.cz/files/iiphdw2013/.

All accepted papers will be included in the conference proceedings indexed by the well-recognized $\mathrm{CPCl}$ database (Thomson Reuters). Selected papers will be recommended for publication within the IAPGOS Journal (ISSN 2083-0157) and Przeglad Elektrotechniczny (ISSN 0033-2097, IF 0.244)

\section{WORKING LANGUAGE}

The Workshop will be conducted in the English language, which is to be used for all printed materials, presentations, and discussion.

\section{COST}

The single conference fee of $250 €$ covers the full board (accommodation +3 meals a day), proceedings, and participation in all workshop-related events. The fee is reduced to $210 €$ for any participant not requiring accommodation.

The registration form is available at: http://www.utee.feec.vutbr.cz/files/iiphdw2013/

Please contact kroutila@feec.vutbr.cz to obtain more info.

\section{CONFERENCE VENUE}

The conference venue, the Brno University of Technology premises at Technická 12, $61600 \mathrm{Brno}$, is a modern, integrated campus situated in the northern part of the city. For more detailed information, please visit the website http://www.utee.feec.vutbr.cz/files/iiphdw2013/

\section{POSTAL ADDRESS}

Brno University of Technology

Department of Theoretical and Experimental

Electrical Engineering

61600 Brno, Technická 12, www.utee.feec.vutbr.cz 